\title{
AMAZÔNIA E "BRASIL": IDENTIDADES DESENCONTRADAS EM UA:BRARI DE MARCELO RUBENS PAIVA
}

\section{AMAZONIA Y "BRASIL": IDENTIDADES DESENCONTRADAS EN UA: BRARI DE MARCELO RUBENS PAIVA}

\section{AMAZÔNIA E "BRASIL": DISENGAGED IDENTITIES IN MARCELO RUBENS PAIVA' S UA:BRARI}

\author{
Danielle Santos Rodrigues \\ Universidade Federal de Sergipe (UFS/CAPES), Brasil. \\ danirodrigues1202@gmail.com \\ Luiz Eduardo da Silva Andrade \\ Universidade Federal de Minas Gerais (UFMG); Brasil \\ luiz-eduardo@ufmg.br
}

\begin{abstract}
Resumo:
O objetivo deste artigo é revisar a construção de algumas nuances da identidade brasileira a partir do romance Ua:brari de Marcelo Rubens Paiva. A obra problematiza os percursos da crítica histórico-social e da história literária brasileira quando retorna à Amazônia, já no século XX, para questionar e denunciar o que permanece ocorrendo no Brasil. Diante do pensamento de Prado Júnior, Holanda, Ribeiro e Freyre, este artigo analisaa reprodução do gesto colonizadorlexplorador sobre a Amazônia ainda no século XX; em seguida, dialoga-se com DaMatta em uma crítica da perpetuação de privilégios na formação de uma elite nacional; por fim, trata-se do problema do messianismo e dos vários populismos que assolam o país. Conclui-se que há uma espetacularização nacional $e$ internacional na forma como a Amazônia é apresentada, colaborando para um desencontro e um desacordo entre as nossas identidades.
\end{abstract}

Palavras-chave: Amazônia, Brasil, Identidade, Ua:brari, Marcelo Rubens Paiva.

\section{Resumen:}

El objetivo de este artículo es revisar la construcción de algunos matices de la identidad brasileña a partir de la novela Ua:brari de Marcelo Rubens Paiva. La obra problematiza los recorridos de la crítica histórico-social y de la historia literária brasileña cuando retorna a la Amazonia, ya en el siglo XX, para cuestionar y denunciar lo que permanece ocurriendo en Brasil. Ante el pensamiento de Prado Júnior, Holanda, Ribeiro y Freyre, este artículo analiza la reproducción del gesto colonizador/explorador sobre la Amazonia aún en el siglo XX; más adelante, se recurre a DaMatta para una crítica de la perpetuación de privilegios en la formación de una élite nacional; por último, se trata del problema del mesianismo y de los varios populismos que asolan el país. Se concluye que hay una espectacularización nacional $e$ internacional en la forma como la Amazonia es presentada, colaborando para un desencuentro y un desacuerdo entre nuestras identidades. 
Palabras clave: Amazonia, Brasil, Identidad, Ua:brari, Marcelo Rubens Paiva.

\begin{abstract}
:
This article review the construction of some aspects of Brazilian identity from the novel Ua:brariby Marcelo Rubens Paiva. The text problematizes the paths of historical-social criticism and Brazilian literary history when it returns to the Amazon, already in the 20thcentury, to question and denounce what is still happening in Brazil. Starting from Prado Junior, Holanda, Ribeiro and Freyre, this article analyzes the reproduction of the action colonising/explorative on the Amazon in the20thcentury; later, with DaMatta there is a critique of the perpetuation of privileges in the formation of a national elite; at last, have the problem of messianism and the various populisms that devastate the country. In the conclusion we note that there is a national and international spectacularization in the way the Amazon is presented, contributing to a disagreement between our identities.
\end{abstract}

Keywords: Amazon, Brazil,Identity,Ua:brari, Marcelo Rubens Paiva.

Recibido:12 de abril de 2018

Aceptado: 30 de mayo de 2018

\title{
1. Prelúdio
}

O crítico literário brasileiro Roberto Schwarz, em Ao vencedor as batatas, no capítulo "As ideias fora do lugar", lembra que a matéria do artista em nosso país "é historicamente formada e registra de algum modo o processo social a que deve a sua existência" (Schwarz 31). Seguindo esse pensamento, a produção no Brasil, ainda que indiretamente, tende a reverberar, em graus diversos de profundidade e problematizações, questões históricas da formação da nossa nação, desde o processo de colonização até a atualidade. Isso nos faz refletir sobre o estado ou Estado que nos circunda, responsáveis por variados fatores que dinamizam os núcleos e fragmentos da composição identitária nacional.

O romance Ua:brari, de Marcelo Rubens Paiva, é a terceira obra do autor. Publicada em 1990, a narrativa apresenta uma estrutura mais experimental e, no desenvolvimento da intriga, faz diversas críticas ao empresariado brasileiro, ao governo e aos militares, principalmente no tratamento dado aos indígenas e à Amazônia, complicação central do enredo. A história também faz variadas referências à mística que compõe o caleidoscópio da formação religiosa nacional, cada dia mais intolerante à diversidade.

O narrador-protagonista de Ua:brari é Fred Klima, jornalista de um importante jornal. Filho de um rico empresário, agora falido, o rapaz conviveu na infância e na juventude com 
herdeiros das famílias mais ricas do país. Em uma festa dos antigos amigos do colégio, Fred reencontra Bia e inicia um caso amoroso. Só que Bia está noiva de Júlio, irmão caçula de Zaldo, amigo de Fred no passado. Júlio e Zaldo são filhos de Antônio Levell, um dos empresários mais abastados e influentes do Brasil.

No seguimento da trama Fred é convocado pelo seu patrão para uma reunião urgente, na casa de Antônio Levell. Lá, além do empresário, estão presentes figuras como o Ministro da Justiça, o diretor da Polícia Federal e o Cônsul da Venezuela. Todos organizam uma expedição à Amazônia para solucionar um conflito que se inicia entre as nações brasileira e venezuelana. A missão de Fred é descobrir o paradeiro de Zaldo, que, durante uma viagem de pesquisa para o grupo Levell, desapareceu na Amazônia. Meses depois soube-se que Zaldo está numa região fronteiriça com a Venezuela, um local problemático, foco de guerrilha, e lá lidera uma seita na qual é tratado como messias pelos povos da floresta.

Os nativos chamam-no de "Ua:brari”, que, segundo a lenda dos índios Macuxi, é o nome do jovem que conhecia o caminho para o outro lado do mundo. Júlio, irmão de Zaldo, acompanha Fred na jornada. Ao chegar ao acampamento, tateando entre os mistérios que circundam a seita e a figura fantasmagórica de Zaldo, Fred descobre histórias de corrupção e mentira protagonizadas pelo Estado, militares e guerrilheiros, os quais ameaçam a sobrevivência da Amazônia e de todos seus habitantes.

Apresentadas as questões mais relevantes para a nossa leitura da obra, cabe esclarecer que este trabalho visa analisar a construção de algumas nuances da identidade brasileira explicitadas por Marcelo Rubens Paiva em Ua:brari.

É importante salientar que, diferentemente do ocorrido no Romantismo e no Modernismo, o romance ora abordado não explicita quaisquer intenções de se criar um imaginário acerca do Brasil, ainda que o faça por conta do registro narrativo. Mesmo assim, a proposta da obra de Paiva é diferente das duas estéticas citadas, uma vez que nelas, simbolicamente, muitas obras foram escritas como meio de traçar um caráter da nação. Além disso são narrativas que tanto "fundaram" quanto "questionaram" uma tradição literária nacional, cada uma ao seu modo e ao seu tempo, respectivamente.

Dessa forma, pressupomos, antes, que Ua:brari parece problematizar, entre tantos percursos críticos, uma identidade nacional baseada na grandiosidade da natureza, haja 
vista trazer uma Amazônia agonizante como espaço central da narrativa. A problematização ocorre pelo viés da denúncia, em que se destaca a destruição da natureza, sem se prender ao discurso laudatório das belezas e da extensão territorial. Seria o caso de sugerir que a obra de Marcelo Rubens Paiva se inscreve numa tradição literária já apontada por Machado de Assis no ensaio "Instinto de nacionalidade". Nesse texto, o escritor realista salienta a importância da confluência de literatura e natureza na formação da nação ao dizer que

interrogando a vida brasileira e a natureza americana, prosadores e poetas acharão ali farto manancial de inspiração e irão dando fisionomia própria ao pensamento nacional. Esta outra independência não tem Sete de Setembro nem campo de Ipiranga; não se fará num dia, mas pausadamente, para sair mais duradoura; não será obra de uma geração nem duas; muitas trabalharão para ela até perfazê-la de todo (Assis 158).

Ao ocupar esse lugar dentro das narrativas que a cada geração discutem o Brasil e a identidade de seu povo, Ua:brari cumpre um papel de desconstruir um imaginário cultural de nação baseado na idealização da natureza, iniciado ideologicamente no Romantismo e resgatado no Modernismo. A narrativa se interliga com as obras de diversas gerações de autores e contribui, ao trazer um pensamento crítico, reflexivo, para a formação da "fisionomia própria ao pensamento nacional", apontada por Machado de Assis.

A partir dessa primeira apresentação, retomamos nossos objetivos de análise em Ua:brari, os quais versam, mais especificamente, sobre abordagem de três pontos, que são: a reprodução do comportamento colonizador/explorador português na Amazônia do século $\mathrm{XX}$; a formação de uma elite nacional que se mantém por meio de uma perpetuação de privilégios transferidos via sucessão; e o messianismo como uma tentativa de criar uma nova sociedade brasileira.

\section{Uma nova colonização/exploração da Amazônia no século XX}

A colonização do Brasil e da América Latina, desde seu princípio, foi pautada pela exploração dos recursos naturais de grande valor comercial e pela progressiva aniquilação dos povos nativos. Diferentemente das colônias da zona temperada, onde o objetivo da emigração era o povoamento e o trabalho dos emigrantes com a terra; nas colônias tropicais se assume um caráter exclusivamente mercantil, no sentido de extrair matérias-primas que gerariam 
lucro para o comércio europeu. Conforme aponta Caio Prado Júnior, em Formação do Brasil contemporâneo,

se vamos à essência de nossa formação, veremos que na realidade nos constituímos para fornecer açúcar, tabaco, alguns outros gêneros; mais tarde ouro e diamantes; depois, algodão, e em seguida, café, para o comércio europeu. Nada mais que isto. É com tal objetivo, objetivo exterior, voltado para fora do país e sem atenção a considerações que não fossem o interesse daquele comércio, que se organizarão a sociedade e a economia brasileiras (Prado Júnior 32).

Assim, fundamenta-se o Brasil como um exportador sem lucro, tendo sua agricultura e, posteriormente, indústria, voltadas para o mercado externo. A visão da terra na qual plantando, tudo dá, mencionada já no descobrimento em 1500 na Carta de Caminha quando este diz que "é graciosa que, querendo-a aproveitar, dar-se-á nela tudo" (Caminha 11), delineia uma abnegação construída pelo poder português por meio da subjugação e exploração do território, dos indígenas e, depois, dos africanos, quando os primeiros já não são úteis aos trabalhos forçados. Traça-se, desde aí, a essência do país, os ditames de nossa constituição que ecoam e moldam a sociedade brasileira ainda hoje, como se essa memória reverberasse seus reflexos nos mais diversos lugares da nossa história.

Não é à toa que todas essas violências são recuperadas na trama de Ua:brari, ainda que se passe no final do século XX. O contexto é outro, mas não menos problemático, já que a história do romance ocorre poucos anos após o golpe civil-militar de 1964, amplamente mencionado na obra. Nesse caso, o país vivencia uma transição política, econômica, ideológica que traz, de modo mais profundo, as consequências desse período ditatorial, o qual relembra outras formas de violência impostas à nação desde o período em que era colônia.

Para Sérgio Buarque de Holanda, em Raízes do Brasil, a pouca capacidade dos portugueses, de racionalizar a vida, fez com que o governo representasse o princípio unificador que atuava como um "tipo de organização política artificialmente mantida por uma força exterior e que, nos tempos modernos, encontrou uma das suas formas características nas ditaduras militares" (Holanda 38). No romance de Marcelo Rubens Paiva, ambientado na Amazônia, o Estado é representado pelo exército. Essa força é o elemento normatizador que, mesmo com o fim da ditadura, permanece no território amazônico controlando a população, principalmente a indígena, e as fronteiras. 
À semelhança do colonizador português que, ao chegar ao Brasil, conseguiu obter informações e auxílio dos índios intercambiando objetos, em Ua:brari este papel é desempenhado pelos militares. O narrador recebe essa denúncia de Bernard George, um antropólogo americano que vive na Amazônia:

Enquanto demoramos cinco anos para ganhar a confiança dos índios, o Exército só precisa de horas com presentes como Toyotas, bicicletas, motores pra barco. Quem não gosta de presentes?... Não se pode culpar os índios. Em algumas coisas não são tão diferentes de nós. [...] Todo o Exército está mobilizado para conquistar os índios. Estão gastando fortunas. E para quê? Não sei se para controlá-los, ou se tem alguma coisa por trás (Paiva 96).

Os presentes mantêm os índios dependentes, predispostos a ajudar seus "benfeitores".Compare-se com o trecho da Carta de Caminha: "Viu um deles umas contas de rosário, brancas; fez sinal que lhas dessem, e folgou muito com elas, e lançou-as ao pescoço; [...] acenava para a terra e novamente para as contas e para o colar do Capitão, como se dariam ouro por aquilo" (Caminha 3, grifo nosso).Assim como no início da colonização, os nativos detêm o conhecimento acerca do território e, em se tratando da Amazônia, esse saber se torna ainda mais premente, pois a grandiosidade da floresta é monstruosa e todos que vêm de fora parecem temer o chamado "fator amazônico".

Sobre isso, esclarece-se no romance: “Aquilo dá medo, enlouquece qualquer um. Seu corpo ganha outra forma, sua voz fica grave e você vira bicho, sempre atacado por tudo. Quando tem índio, então!...” (Paiva 94). O indígena ganha assim, um poder que é ao mesmo tempo sua salvação e condenação. É visto como uma entidade da floresta, um decifrador dos seus labirintos, mas, ao revelar seu conhecimento, se torna descartável, pois seu saber é perigoso e sua essência um mistério. A simbiose entre índios e Amazônia representa obstáculo a ser atravessado na exploração comercial pretendida pelo Estado e pelos empresários brasileiros em Ua:brari.

Em determinado ponto da sua vivência na Amazônia, perante todas as visões que lhe foram apresentadas e fatos que presenciou, Fred Klima conclui:

Ninguém é dessa terra, ninguém tem raízes aqui, exceto os índios. Todos que vêm um dia vão. Em toda a Amazônia, a parada é rápida. Estão aqui para arrancar o quanto podem e ir arrancar em outra parte. É por pouco tempo, arrancar antes que acabe. Ficam os índios que 
conseguirem sobreviver com a lama, restos, uma floresta cinza (Paiva 131).

A molde de espelho, Ua:brari posiciona exploradores e indígenas em realidades equivalentes às vividas na colonização. Como afirma Darcy Ribeiro, "levamos quinhentos anos para ocupar o território e incorporar, ou matar, ou dizimar aqueles indígenas que não tinham desenvolvimento social suficiente" (Ribeiro, Sobre 199). A Amazônia, no romance, assume valor de um microcosmo onde se reproduz e se perpetua o comportamento colonizador que visa retirar da terra, até extenuá-la, todo o lucro possível. As primeiras vítimas desse desenvolvimento comercial de natureza exploratória permanecem sendo as comunidades indígenas que sofrem as consequências desta agressão ecológica e cultural.

Diante da Amazônia, os primeiros europeus "ao verem a floresta portentosa, acreditaram ter encontrado, por fim, o tão buscado paraíso perdido. O mais remarcável, a seus olhos, eram as gentes [...] às quais atribuíam a inocência do primeiro dia da criação" (Ribeiro, Amazônia 13-14). Em passagens de Ua:brari, os indígenas são associados ao místico devido ao domínio dos elementos da natureza e à capacidade premonitória - e ao exótico, chegando a serem apresentados como atrações circenses, à semelhança de um freakshow. Contudo, o maior destaque feito pela narrativa de Marcelo Rubens Paiva é a tentativa de desenraizar os índios, aculturando-os, dissolvendo-os na massa brasileira a fim de que deixem de constituir obstáculo para a exploração das grandes riquezas da floresta.

Em uma conversa que o narrador tem com Hollywood, general de nome irônico responsável pelo Exército na Amazônia, é possível entrever a defesa do progresso da região construída a partir de uma tentativa de "expatriar" as comunidades indígenas, retirando-as de territórios demarcados:

- [...] A economia brasileira não pode ser guiada por impulsos românticos... [...] Esses índios não deveriam ficar confinados em reservas demarcadas. Seria mais válido integrá-los ao país, tornandoos brasileiros. O Brasil precisa deles. E eles querem sair, comprar jeans, relógios, óculos escuros e uma TV Panasonic. A cultura deles é baixíssima e não é respeitável... [...] Tanto ouro para ser descoberto. Ouro, bauxita, diamante, cassiterita, tanta madeira que vale uma fortuna... Deixem essa gente explorá-la, não é verdade? (Paiva 128). 
O general Hollywood utiliza a cultura indígena, a qual inferioriza, como argumento para a diluição dos índios na sociedade brasileira. Nesse ponto da história há uma intersecção com a ideia portuguesa de que era preciso civilizar os índios, torná-los engrenagens da máquina colonizadora. A visão negativa da cultura indígena, denunciada em Ua:brari, não se restringe aos desejosos de usufruir as riquezas amazônicas. O próprio Gilberto Freyre, em Casa-grande \& senzala, reproduz traços da visão do colonizador ao afirmar que os portugueses vieram defrontar-se na América com "uma das populações mais rasteiras do continente. [...] Quase que bandos de crianças grandes; uma cultura verde e incipiente; ainda na primeira dentição" (Freyre 310).

É sobre essa premissa que se delineou todo o processo de aniquilação, exploração, absorção e aculturação indígena. Ainda no século XVI, no Brasil, "todas as suas terras já tinham dono e nenhum deles era indígena" (Fraxe, Witkoski e Pereira 18). Sendo "crianças", os nativos não precisavam de terras, mas, sim, de um "pai" que regesse seus interesses. A narrativa de Marcelo Rubens Paiva, ao atualizar esse contexto para o século XX, vai ainda além ao colocar, implicitamente, na fala do general o discurso corriqueiro entre os parte dos ruralistas latifundiários hoje. Tal discurso defende que os povos nativos devem escolher entre possuir um território ou ter acesso a bens de consumo, como TV e relógio.

Nota-se que a problematização ficcionalizada em Ua:brari apresenta a Amazônia como um espaço que "tem sido percebido antes como produto do mercado, ele próprio a mercadoria" (Fraxe, Witkoski e Pereira 50). Os povos indígenas devem ser aproveitados na exploração desse espaço, mas, se recusarem a bondade do progresso civilizador, permanecerão perseguidos, sendo as alteridades da nação que um dia foi apenas sua.

Marcelo Rubens Paiva, por meio do personagem Aríton, um agente amazônico da Polícia Federal que acompanha Fred na expedição, ensaia uma possibilidade entre os rumos da miscigenação:

Um índio, não índio, mas índio. Poucos saberiam descrever o que ele realmente suporta. Dois polos, vidas, movimento. Uma fala de dentro: use as mãos, o cheiro, veja longe, verdes! O outro come ruídos, galopa em quatro rodas, não faz o que sente, ordens! Quem não tem dois jeitos de ser? Mas ninguém dois tão distantes. Vinte mil anos, talvez, o número (Paiva 168-169). 
Diversos grupos, principalmente a partir da década de 1930, se estabeleceram na Amazônia a fim de desempenhar atividades extrativistas, como acoleta do látex que deu início ao período da borracha. "Nesta época, explodiu fortemente o contato e a miscigenação entre brancos, índios e negros na Amazônia, permitindo, a um só tempo, a canibalização de culturas e a desagregação dos espaços" (Fraxe, Witkoski e Pereira 25). O personagem Aríton é fruto da miscigenação desses povos o que o coloca nesse não-lugar.

Marcelo Rubens Paiva parece estabelecer um vínculo com o surgimento do mameluco, apontado por Darcy Ribeiro (Cit. em Sobre 199) como o filho do homem branco com a índia. O mameluco possuiria todos os saberes indígenas, falaria a língua da mãe, mas não se identificaria com ela, e sim com o pai. Para Ribeiro, a adaptação e sobrevivência do português foi "dada através dessa herança que o mameluco recebe da mãe. Ou seja, o mestiço castigador do gentio materno, caçando índios por toda a parte, era um descendente de índios" (Ribeiro, Sobre 199).

Aríton, enquanto agente federal, cumpridor das ordens de um Estado que, na narrativa, hostiliza os povos indígenas, se aproxima do mameluco descrito por Darcy Ribeiro. $\mathrm{O}$ autor de Ua:brari, ao delinear dessa forma a única personagem que problematiza a miscigenação, nos coloca diante de uma perspectiva desesperançada, como se, mesmo séculos depois, nada de positivo pudesse advir das tentativas de união entre os exploradores de territórios e os indígenas que os habitam.

\section{Formação de uma elite nacional: resquícios dos privilégios herdados}

A história da ocupação sucessiva de cargos públicos por membros da mesma família está no cerne do Brasil, desde a época colonial. Comum nos três poderes - executivo, legislativo e judiciário -, a prática de transmitir entre as gerações privilégios adquiridos, é ainda maior quando se trata de empresas do setor privado. Nada mais normal, não houvesse, em nosso país, uma rede favorecimentos entre os setores público e privado, fora o elevado número de empresários que ocupam também cargos políticos e, assim, obtêm benefícios em seus negócios.

O apadrinhamento político, sobretudo em casos de familiares, remonta o sistema colonial das Capitanias Hereditárias, criado por Dom João VI para administrar o território 
brasileiro. Essa prática marcou o prosseguimento de certos sobrenomes na política nacional por muitos anos.

Dialogando com esse (mau) costume, Ua:brari conduz o leitor a uma análise crítica do nepotismo e da troca de favores que imperam no Brasil. No início do romance, sabe-se que Zaldo, filho e executivo na empresa de Antônio Levell, viajou à Amazônia a trabalho, mas lá acabou adotando um comportamento, dito, confuso e místico. Tempos depois, sabe-se que ele é tratado como um messias e estabelece-se em uma região conflituosa na fronteira entre Brasil e Venezuela. Na iminência de uma ação repreensiva por parte, sobretudo, do governo venezuelano - afinal, além de invadir o território da Venezuela, o número de adeptos de Zaldo crescia vertiginosamente - o empresário Antônio Levell usa sua influência dentro dos governos brasileiro e venezuelano para enviar uma expedição cujo objetivo era salvar Zaldo, trazê-lo de volta para a casa da família em São Paulo.

A presença de certas personalidades, no casamento de Júlio e Bia, representa bem o grau de influência e a rede de amizades dos quais dispunha a família Levell:

Quase todo o parque industrial de São Paulo, e por que não dizer do Brasil, estava presente. O Produto Interno Bruto daquele salão era maior do que o da maioria dos países do Terceiro Mundo. Presentes três ministros de Estado e quatro ex-ministros, esposas e filhos. Presentes também quase toda a diretoria da FIESP, o presidente da Associação Comercial do Estado, os presidentes da BOVESPA, da TELESP, da SABESP, do INAMPS, Secretários do Estado (Paiva 17).

Desse modo, a fim de auxiliar o "amigo", há uma grande mobilização da qual tomam parte o presidente, ministros de Estado, Exército, Polícia Federal e Consulado venezuelano. Tudo isso para salvar Zaldo de uma possível prisão, algo que, como demonstra a narrativa, ocorreria naturalmente e há muito tempo, se ele não fosse filho de alguém financeiramente tão agraciado como Antônio Levell. A respeito desse comportamento representado na obra, Sérgio Buarque de Holanda abrange para uma leitura da nossa história e nos esclarece que:

No Brasil, pode dizer-se que só excepcionalmente tivemos um sistema administrativo e um corpo de funcionários puramente dedicados a interesses objetivos e fundados nesses interesses. [...]. As relações que se criam na vida doméstica sempre forneceram o modelo obrigatório de qualquer composição social entre nós (Holanda 146). 
O romance de Paiva retrata a falta de objetividade da esfera pública que se subjuga ao poder de um empresário. Antônio Levell não só impede as ações punitivas que caberiam a seu filho, no Brasil e na Venezuela, mas também consegue converter essas ações em um elaborado planejamento para salvar o rapaz. A domesticidade da qual fala Holanda, no excerto anterior, é evidenciada quando a reunião com todos os representantes dos diversos poderes ocorre na casa do empresário, durante um almoço de domingo.

Outro paralelo que Ua:brari nos faz defrontar é com o costume do "sabe com quem está falando?" trabalhado por Roberto DaMatta. A hierarquia presente no romance é vista como algo natural, tanto que a entrada de Bia na igreja, no dia de seu casamento, reproduz grosseiramente índices da escravidão, contudo, nenhum dos presentes, nem mesmo o narrador, notam o absurdo da chegada da noiva:

Quatro negros envoltos em panos dourados e com turbantes na cabeça conduziam uma cadeirinha coberta, decorada com flores. Esperava tudo: Rolls Royce, charrete com cavalos brancos. Jamais uma liteira com quatro sujeitos carregando; bem que ela me avisara que eu teria uma surpresa na sua chegada. O "veículo" deu a volta ao redor da igreja, como uma peça a ser leiloada. Algumas crianças correram atrás. Palmas. Finalmente estacionou (Paiva 14-15).

A referência utilizada por Bia foi a da senhora branca sendo carregada por negros, seus servidores-escravos. Há uma completa ausência de estranheza ou desconforto por parte dos convidados que parece advir não de um desconhecimento desse terrível momento da história brasileira, a escravidão, mas da falta de identificação com esse lugar do outro que, em se tratando de um país miscigenado como o nosso, também compõe o nosso próprio lugar. Contudo, as pessoas presentes no casamento não reconhecem o lugar do escravo como seu. Retomando o estudo do "sabe com quem está falando?", Roberto DaMatta afirma que esse rito

nos coloca muito mais do lado das escalas hierárquicas e dos caxias que sistematicamente queremos esconder ou, que dá no mesmo, achamos que não temos a necessidade de mostrar, pois "cada qual deve saber o seu lugar" - do que das associações espontâneas, livres e amorosas dos futebóis, cervejas na praia, carnavais e samba (DaMatta182, grifo do autor). 
Essa passagem nos faz pensar que o lugar onde os convidados de Bia se colocam, na escala hierárquica, é o do senhor de escravos. Esse seria um local herdado, não por serem os presentes, exatamente, sucessores de grandes senhores de terra, antes, trata-se de uma identificação baseada no poderio econômico que possuem, por isso são incapazes de visualizar a entrada de Bia, no mínimo, como uma escolha infeliz.

A ideia de que "cada qual deve saber o seu lugar", nessa cena do romance, revela os valores e desvalores de uma classe social abastada que deixa entrever uma falha no verniz da igualdade racial, no discurso contrário ao preconceito, adotado pela maioria dos brasileiros. Percebe-se que, por maior que seja a distância temporal e as transformações econômicas e sociais, persiste, de forma naturalizada, a hierarquia pautada na cor da pele, os vícios do tratamento senhor-escravo, tão comuns há pouco mais de um século. Corroborando com isso, Bia vangloria-se de sua entrada "incrível".

Ainda sobre a festa do casamento, Fred narra:

Havia outra festa no banheiro. Entre eles, a irmã do noivo, um sujeito que me apresentaram como Bola, primo do noivo, magro como uma caneta, e mais alguns futuros membros do inventário da indústria paulista, herdeiros do país, muitos dos quais eu conhecia. [...] Ao longo da pia, várias carreiras de pó formavam a palavra "BRASIL". Estavam consumindo o "B", quando me ofereceram. Não, obrigado (Paiva 20).

Quando o autor coloca os herdeiros de grandes famílias consumindo carreiras de cocaína que escrevem "Brasil", constrói uma poderosa alegoria da classe dominante como consumidora do país. A nação é tratada como algo pertencente a essa classe que a consome pouco a pouco, como posse sua, até chegar o momento em que não restará mais nada, nem o pó, e tudo para mera recreação. A crítica presente em Ua:brari se encontra com o pensamento de Darcy Ribeiro quando este denuncia que

o povo brasileiro vem lutando contra uma classe dominante infecunda. O problema não é o povo, não é o pobre, não é o feio; é o bonito, o educadinho, o serviçal da multinacional, o tecnocrata - esse que é o bandidinho, e estão todos de acordo com a ordem. [...] o que realmente há de ruim e que não deixa este país dar certo é que este país deu muito certo para a sua classe dominante, que sempre foi rica, sempre passou muito bem, muito contente com o Brasil tal qual é (Ribeiro, Sobre 205-206). 
Ua:brari traça um perfil dessa classe dominante que cria e mantém a desigualdade social. A narrativa leva o leitor a refletir sobre os privilégios dessa classe que se configuram como empecilhos para o alargamento de direitos sociais e políticos e distribuição de renda. A prática da hereditariedade, da transmissão da herança financeira e política persiste desde a colonização e a narrativa de Marcelo Rubens Paiva expõe essa chaga, tão evidente, que embarga o desenvolvimento igualitário do Brasil.

\section{Messianismo na tentativa de criar uma nova sociedade brasileira}

Maria Izaura Queiroz, em $O$ messianismo no Brasil e no mundo, utiliza o vocábulo "messianismo" significando dois processos sociais distintos:

A crença na vinda de um enviado divino, que trará aos homens justiça, paz e condições felizes de existência; 2) a ação de um grupo obedecendo às ordens do líder sagrado, que vem instalar na terra o reino da sonhada felicidade. A crença nasce do descontentamento, cada vez mais profundo, de certas coletividades, diante de desgraças ou de injustiças sociais que as acabrunham; afirma formalmente a esperança numa transformação positiva das condições penosas de existência a se produzir (Queiroz 383).

Em Ua:brari, Zaldo lidera um movimento messiânico no qual é "endeusado por garimpeiros, missionários, seringueiros, pescadores, caçadores, fanáticos, membros da diocese, tapuios, soldados desertores do exército e, como se não bastasse, jovens da altaburguesia, amigos de Zaldo" (Paiva 68). Essas pessoas têm em comum o descontentamento apontado por Queiroz. Ao contrário do que se poderia pensar, o paraíso que os adeptos de Zaldo busca não está em um plano imaginário, na crença de um céu que virá após a morte. O paraíso para eles está no real, na possibilidade de viver em uma comunidade onde imperem a natureza, a fartura de alimentos e, principalmente, a igualdade social.

Os seguidores de Zaldo tentam formular uma sociedade diversa, uma alternativa à sociedade brasileira, precária e excludente. A maioria dos adeptos da seita são alteridades, a exemplo dos indígenas que seguem o rapaz por acreditar que ele é capaz de orientá-los e "proteger o seu povo, vingando os agressores, matando-lhes doença e loucura". (Paiva 136). Os índios não acreditam exatamente que Zaldo é Deus, o seguem, por ver nele uma esperança 
de terra e paz. Esse líder prometeu doar terra para os índios, um “parque com escritura, grande o suficiente para abrigar muitas nações. O pai dele é rico. Todos sabem disso" (Paiva 171).

Quando Fred chega ao acampamento, passa dias sem ter notícias de Zaldo, dizem que ele está em toda a parte e, algumas vezes, na calada da noite, visita alguma moradia levando palavras de sabedoria e conforto. A narrativa deixa entrever que Zaldo objetivava recuperar a dignidade dos seus seguidores, desfavorecidos na antiga sociedade em que viviam. Há no movimento, uma tentativa de transformar a terra em que vivem tornando possível uma nova vida coletiva. As pessoas se dividem em tarefas, de modo espontâneo. Alguns plantam, outros constroem casas, pontes, cozinham e distribuem os alimentos. Todos parecem empenhados no projeto do lugar e acreditam que ali alcançarão um sentido para a vida, uma existência ideal.

Porém, o movimento perde o controle. Os seguidores erguem um templo na esperança de que Zaldo finalmente se mostre a todos, o que não ocorre. A ausência do mestre gera grande comoção e muitas pessoas abandonam o acampamento. O templo, abandonado, passa a ser ocupado por adeptos do Santo Daime. Em uma noite de celebração, Zaldo aparece no templo. Sua entrada é semelhante à de Jesus quando expulsa vendedores e cambistas do Templo de Jerusalém. Do mesmo modo intempestivo, Zaldo interrompe o ritual do Santo Daime e afirma a todos:

- O meu reino é o da igualdade. É o reino da verdade. Você é flor, é animal, é uma gota de chuva, um pedaço do céu. No meu reino você não pede, não chora, não ri, não existe. No meu reino, somos iguais. Do mar ao vento. Do céu à terra. Somos uma coisa só. Somos vida. Vocês viram que certos sonhos podem ser reais. [...] E digo a vocês. Houve um tempo em que as trevas cobriam a face do abismo e fez-se a luz. Separou água das águas, produziu a terra, a semente, o verde e fez os peixes, as aves, os animais. Houve um dia em que se fez os homens, e vocês estão aqui. [...] Haverá um dia que a ira jogará fogo sobre a Terra! Choverá pedras e o sangue cairá em vocês! Eu sou o princípio. Eu sou o fim. Acabou. Vão embora! (Paiva 195-196).

Há passagens, na fala do personagem, que remetem, principalmente, aos livros do Gênesis e do Apocalipse. Zaldo mimetiza o comportamento e palavras atribuídos a Jesus. Após o pedido para que todos fossem embora, Zaldo põe fogo no templo, que fica totalmente destruído. Posteriormente, em um encontro mediado por índios e guerrilheiros, ele esclarece a 
Fred o assombro que sente com a grande proporção que o movimento tomou, sobretudo com a participação dos índios e dos guerrilheiros, e o consequente peso que foi colocado sobre ele:

- Eu tive a visão. E de repente, estava cercado, e queriam mais, sempre mais. Estou confuso, Fred. Vocês me deixaram confuso, não é incrível? Um rei não sente o peso da coroa, nem duvida do seu poder. Estou confuso e cansado... [...] Olhe só - apontou para as pessoas ao redor. - Estão me usando. Lutam pela sua sobrevivência. [...]. Esta fumaça vermelha que você vê, é para nos esconder por instantes, enquanto a lança faz a curva no céu. Ela vai descer. Estou aprisionado, sem forças, e sinto medo... [...]. Eu quero ir embora. Me tira daqui. Vamos embora (Paiva 197-198).

Fred e Zaldo conseguem um barco e iniciam a fuga, porém mal avançam sobre o rio e Zaldo leva um tiro no peito. A bala é a lança que Zaldo cita, a qual remete à lança que trespassou Jesus Cristo na cruz. Fred descobre, tempos depois, que o tiro que matou o amigo veio de um local em que os únicos presentes eram o irmão Júlio, que odiava Zaldo por conta de um caso amoroso que este teve com Bia, e o general Hollywood, que teve seus interesses financeiros comprometidos por Zaldo.

O movimento messiânico construído por Marcelo Rubens Paiva em Ua:brari apresenta o esboço de uma sociedade alternativa, igualitária, contudo não alcança seu objetivo de fazer vigorar um novo sistema de vida independente do sistema social brasileiro. A força coletiva que busca essa transformação, Zaldo e seus adeptos, não consegue perpetuar a nova vida regida por valores diversos dos da antiga sociedade que habitavam. As expectativas dos adeptos, em sua maior parte formados por excluídos e divergentes do modelo de vida social que impera no Brasil, sucumbem, como Zaldo, diante da especulação comercial e da busca de poder representadas pela burguesia nacional, políticos, militares e guerrilheiros.

Este cenário descrito no romance parece assim alegorizar a destruição de todas as tentativas de construção de uma nova sociedade nacional que buscavam solucionar a desigualdade e carência registradas ao longo de nossa história, a exemplo do ocorrido em Canudos no final do século XIX. 


\section{Considerações finais}

Para o desenvolvimento deste ensaio, inicialmente mostrou-se como o romance de Marcelo Rubens Paiva discute todo o processo de exploração das riquezas da Amazônia, o qual se converte também em exploração do seu povo. O ponto extremo dessa violência são os momentos em que se confrontam os discursos do colonizador contemporâneo com as observações de que o indígena é forçado a não reconhecer seu lugar como nativo e passa a ser o estranho. Da mesma forma que se extraiu muito dos elementos naturais, tenta-se extrair do indígena sua "essência" para que "civilizado" se torne um "brasileiro".

Tamanha conversão não nasce durante a Ditadura Civil-Militar, mesmo assim reproduz um modelo de dominação econômico-ideológica que vem desde a colonização europeia. O percurso traçado passou por Caio Prado Júnior e sua visão econômico-social da constituição do nosso ideal nacional, depois por Sérgio Buarque de Holanda naquilo que critica o modelo colonial e demonstra seus reflexos na nossa formação identitária. Por fim, com Darcy Ribeiro, demonstra-se o processo de aculturação como o passo "final" da aniquilação do "ser indígena”. Simbolicamente, as trocas econômicas e culturais se equivalem em muitos aspectos, pois ambas visaram apenas à exploração do indígena e da Amazônia.

No segundo momento, a discussão se deslocou da expropriação do indígena para discutir o estabelecimento de "domínios" territoriais, os quais se convertem no estabelecimento de uma elite financeira e cultural que ditará a história "oficial" da nação com seus sobrenomes "casados" e perpetuadosà custa do "esquecimento" do outro. Naturalmente que essa cegueira é circunstancial eimpede que essa elite tenha clareza desse seu lugar de dominação, cujo traço mais forte é a naturalização de violências que remontam a escravidão, a exemplo do casamento de Bia e todo ritual de entrada na igreja.

Dessa forma, o romance chega a um dos pontos mais críticos, que é o de apresentar os "filhos da elite" reiterando práticas que em nada mudam o sistema exploratório das riquezas do povo brasileiro. De alguma forma, no casamento entre pares, na presença dos seus "iguais" poderosos, a narrativa desconstrói qualquer possibilidade de se reafirmar a mestiçagem como sendo um elemento ímpar da nossa formação. Elemento esse que tem sido utilizado de forma espetacularizada em diversos contextos, sem a devida assimilação do que significa. 
$\mathrm{Na}$ terceira e última parte, o messianismo aparece como a grande ironia do romance de Marcelo Rubens Paiva. Zaldo e suas similaridades com outros "messias" demonstra não só a carência do nosso povo, como também a ironia de uma sociedade igualitária nunca se converter em realidade, talvez por isso a escolha do autor se ajuste tão bem aos discursos "utópicos" de fazerem do Brasil uma nação dos "brasileiros".

Por mais que a restituição desse lugar-comum do discurso do Brasil para os brasileiros seja uma quimera da realidade, essa restituição ultrapassa a barreira do puro idealismo quando aparece na literatura, pois nos mostra que as narrativas não deixaram de ser produzidas em outros espaços discursivos, além dos oficiais, como bem demonstra Silviano Santiago (15):

No século 20, os nossos melhores livros apontam para a Arte, [...], e ao mesmo tempo apontam para a Política, ao querer denunciar pelos recursos literários não só as mazelas oriundas do passado colonial e escravocrata da sociedade brasileira, mas também os regimes ditatoriais que assolam a vida republicana. A atividade artística do escritor não se descola da sua influência política; a influência da política sobre o cidadão não se descola da sua atividade artística. [...]. Ao dramatizar os graves problemas da sociedade brasileira no contexto global e os impasses que a nação atravessou e atravessa no plano nacional, a literatura quer, em evidente paradoxo, falar em particular ao cidadão brasileiro responsável. Não são muitos, infelizmente.

\section{Bibliografia}

Assis, J. Machado. Esaú e Jacó; Críticas literárias; Críticas teatrais. São Paulo: Formar, (sin fecha).

Caminha, Pero Vaz de. Carta a El Rei D. Manuel. São Paulo: Dominus, 1963.

DaMatta, Roberto. Carnavais, malandros e heróis: para uma sociologia do dilema brasileiro. $6^{\circ}$ ed. Rio de Janeiro: Rocco, 1997.

Fraxe, Therezinha de Jesus, Witkoski, Antonio, Pereira, Henrique dos Santos. Amazônia: cultura material e imaterial. São Paulo: Annablume, v. 1, 2011.

Freyre, Gilberto. "Casa-grande \& senzala". Intérpretes do Brasil. Comp. Silviano Santiago. Rio de Janeiro: Nova Aguilar, v. 2, 2000. 203-727.

Holanda, Sérgio Buarque de. Raízes do Brasil. 26 ed. São Paulo: Companhia das Letras, 1995 Paiva, Marcelo Rubens. Ua:brari. São Paulo: Brasiliense, 1990.

Prado Júnior, Caio. Formação do Brasil contemporâneo. $23^{\circ}$ ed. São Paulo: Brasiliense, 2004.

Queiroz, Maria Izaura. O messianismo no Brasil e no mundo. São Paulo: Alfa e Ômega, 1977. 
Ribeiro, Darcy. “Amazônia: homem e cultura em um paraíso ilusório”. Amazônia: a ilusão de um paraíso, ed. Betty Jane Meggers. Rio de Janeiro: Civilização Brasileira, 1977. 916.

Ribeiro, Darcy. "Sobre a mestiçagem no Brasil”. Raça e diversidade. Comp. Lília Scharcz e Renato Queiroz. São Paulo: Edusp, 1996. 187-214.

Santiago, Silviano. "Uma literatura anfíbia”.Revista Alceu. 3.5, (2002): 13-21.Junho 2017. http://revistaalceu.com.puc-rio.br/media/alceu_n5_Santiago.pdf.

Schwarz, Roberto. Ao vencedor as batatas: forma literária e processo social nos inícios do romance brasileiro. $5^{\circ}$ ed. São Paulo: Duas Cidades; 34, 2008. 